Письма в ЭЧАЯ. 2008. Т. 5, №7(149). С. 160-165

ФИЗИКА И ТЕХНИКА УСКОРИТЕЛЕЙ

\title{
DC60 HEAVY ION CYCLOTRON COMPLEX: FIRST BEAMS AND PROJECT PARAMETERS
}

\author{
B. Gikal, S. Dmitriev, P. Apel, S. Bogomolov, O. Borisov, \\ V. Buzmakov, G. Gulbekyan, I. Ivanenko, O. Ivanov, M. Itkis, \\ N. Kazarinov, I. Kalagin, I. Kolesov, A. Papash, S. Pashchenko, \\ A. Tikhomirov, M. Khabarov \\ Joint Institute for Nuclear Research, Dubna \\ K. Katyrzhanov, A. Tuleushev, A. Borisenko, S. Lysukhin, \\ V. Aleksandrenko, V. Dektyaryov, V. Dzyubin, M. Koloberdin, \\ K. Kuterbekov, A. Ushakov \\ Institute of Nuclear Physics, Almaty, Kazakhstan
}

\begin{abstract}
Creation of the DC60 Heavy Ion Cyclotron for the Interdisciplinary Scientific and Research Complex (ISRC) in Astana was started in early 2004. In the summer of 2006 the units of the cyclotron complex after their manufacturing and complex testing at the Flerov Laboratory of Nuclear Reactions, JINR, were delivered to Astana and assembled in the ISRC building. Physical start-up of the cyclotron took place in September 2006 and in December there were obtained accelerated and extracted heavy-ion beams in the whole of the projected range.

The complex based on the DC60 cyclotron is intended for applied and fundamental research using beams of accelerated ions from carbon to xenon with energies from 0.34 to $1.77 \mathrm{MeV} /$ nucleon, as well as for experiments on the channel of low-energy ion beams received from an ECR source with extraction intensities of up to $25 \mathrm{kV}$.

On the DC60 cyclotron the accelerated ions energy variation is carried out through changing the ion charge, a possibility of smooth variation of ion energy by $\pm 30 \%$ of the nominal value by means of changing the cyclotron magnetic field is also envisaged.

Within the framework of commissioning the DC60 cyclotron, a number of experiments have been carried out on accelerating charged particle beams in the main points of the working diagram:

- Investigation of acceleration modes for ions of nitrogen, argon, krypton $\left({ }^{14} \mathrm{~N}^{2+},{ }^{40} \mathrm{Ar}^{4+},{ }^{40} \mathrm{Ar}^{5+}\right.$, ${ }^{40} \mathrm{Ar}^{7+},{ }^{84} \mathrm{Kr}^{12+}$ ) on the 4th and 6th harmonics of $\mathrm{RF}$ accelerating voltage in the whole range of magnetic field variations.

- Investigation of possibilities for bunching the beam with a buncher and of the influence of injected beam intensity on the acceleration efficiency.

- A beam has been extracted from the accelerator with an efficiency exceeding $60 \%$.

- Accelerated ion beam of krypton $\left({ }^{84} \mathrm{Kr}^{12+}\right)$ with a current of up to $2 \mu \mathrm{A}$ was extracted into a beam transport channel, shaped and transported to a technological facility for polymer film irradiation. There has been shaped the irradiation field with a required particle flux density and homogeneity, and experimental irradiation of polymer film has been carried out.

- Investigation of the modes of operational correction of the magnetic field with radial correcting coils of the cyclotron.
\end{abstract}


Создание циклотрона тяжелых ионов ДЦ-60 для Междисциплинарного научно-исследовательского комплекса (МНИК) в Астане было начато в начале 2004 г. После изготовления и комплексной проверки узлов ускорителя в Лаборатории ядерных реакций им. Г. Н. Флерова ОИЯИ циклотронный комплекс был поставлен и смонтирован летом 2006 г. в здании МНИК в Астане. В сентябре был осуществлен физический пуск ускорителя, в декабре 2006 г. получены ускоренные и выведенные пучки тяжелых ионов во всем проектном диапазоне.

Комплекс на базе циклотрона ДЦ-60 предназначен для проведения прикладных и научных исследований на пучках ускоренных ионов от углерода до ксенона с энергий от 0,34 до 1,77 МэВ/нуклон, а также для экспериментов на канале пучков ионов низких энергий, получаемых из ЭЦР-источника с напряжением экстракции до 25 кВ.

Вариация энергии ускоренных ионов циклотрона ДЦ-60 осуществляется путем изменения заряда иона, предусмотрена также возможность плавной вариации энергии ионов $\pm 30 \%$ от номинальной за счет изменения магнитного поля циклотрона.

В рамках программы пуско-наладочных работ на циклотроне ДЦ-60 был выполнен ряд экспериментов по ускорению пучков заряженных частиц в основных точках рабочей диаграммы:

- исследованы режимы ускорения ионов азота, аргона, криптона $\left({ }^{14} \mathrm{~N}^{2+},{ }^{40} \mathrm{Ar}^{4+},{ }^{40} \mathrm{Ar}^{5+}\right.$, ${ }^{40} \mathrm{Ar}^{7+},{ }^{84} \mathrm{Kr}^{12+}$ ) на 4-й и 6-й гармониках высокочастотного ускоряющего напряжения во всем диапазоне вариации магнитного поля;

- исследованы возможности группировки пучка с помощью банчера и влияние интенсивности инжектируемого пучка на эффективность ускорения;

- осуществлен вывод пучка из ускорителя с эффективностью более $60 \%$;

- пучок ускоренных ионов криптона ${ }^{84} \mathrm{Kr}^{12+}$ с током до 2 мкА выведен в ионно-оптический канал, сформирован и проведен до технологической установки по облучению полимерной пленки. Сформировано поле облучения с требуемой плотностью потока частиц и однородностью, и проведено экспериментальное облучение полимерной пленки;

- исследованы режимы оперативной коррекции магнитного поля радиальными катушками циклотрона.

PACS: 29.20.dg

\section{INTRODUCTION}

A specialized accelerating facility based on DC60 cyclotron has been built by the Flerov Laboratory of Nuclear Reactions in collaboration with the Institute of Nuclear Physics (Almaty, Kazakhstan) for the Interdisciplinary Scientific and Research Centre of the Gumilev Euro-Asia National University (Astana, Kazakhstan) [1].

The facility is based on the heavy-ion cyclotron DC60 capable of providing intense beams of heavy ions from lithium $(\mathrm{Li})$ to xenon $(\mathrm{Xe})$ in the energy range from 0.35 to $1.77 \mathrm{MeV} /$ nucleon. The facility is supplied also by the 10 to $25 Z$ low-energy beam channel. Heavy ions are produced by the Electron Cyclotron Resonance (ECR) ion source. The whole facility was designed, built and put into operation in 2004-2006.

The scientific program of the new centre is oriented to solid state physics, nanotechnologies, surface modification of materials, etc. The cyclotron is supplied with three accelerated beam channels. Each channel is provided with set of equipment to solve certain frame problems, while one channel is assigned for specialized production of trace membranes (TM).

New methods of TM production based on different kinds of polymer films as well as different technologies for industrial large-scale manufacturing of TM were developed at the Flerov Laboratory of Nuclear Reactions of the Joint Institute for Nuclear Research (Dubna, Russia). For more than 25 years the technology of nuclear filter production based on irradiation of thin films by heavy-ion beams is being developed and improved on heavy-ion cyclotrons of National Nuclear Centers of USA, France, Germany, Japan, Russia, and other countries. 
Heavy-ion beams of argon (Ar), krypton (Kr), xenon (Xe) of 1-1.5 MeV/nucleon energies are considered as best candidates for polymer films bombardment if one would like to produce TM 10-20 $\mu$ m thick [2].

\section{DC60 CYCLOTRON ARRANGEMENT}

The DC60 cyclotron is a product of FLNR scientific and technology experience acquired on research of U400, U400M cyclotrons, as well as on applied technology cyclotron IC100. Multicharge ions are produced in the ECR ion source [5,6] and are transported by injection channel into the centre of the cyclotron magnet [7], where main acceleration takes place. Beam is extracted from cyclotron by the electrostatic deflector [3].

Magnetic field of the cyclotron is of four sectors structure [4]. Radio-frequency (RF) accelerating system consists of RF amplifier, transmitter line and is loaded by two quarter wave resonators with dees. The variation of radio frequency is fulfilled by moving short circuit plates, located inside the resonance cavities. Two dees are disposed in the free valleys of magnet and are mechanically connected to each other by the strap. The RF power is supplied with one RF generator with frequency variation 11-17.4 MHz. The RF amplifier power is $20 \mathrm{~kW}$.

Heavy ions accelerated at the DC60 cyclotron

\begin{tabular}{|c|c|c|c|c|c|}
\hline Ion & $A / Z$ & $\begin{array}{c}\text { Energy, } \\
\text { MeV/nucleon }\end{array}$ & Magnetic field, T & $\begin{array}{c}\text { Beam current in } \\
\text { the centre of } \\
\text { cyclotron, } \mu \mathrm{A}\end{array}$ & $\begin{array}{c}\text { Beam current at the } \\
\text { extraction radius, } \\
\mu \mathrm{A}\end{array}$ \\
\hline${ }^{14} \mathrm{~N}^{2+}$ & 7 & 1 & 1.42 & 10.5 & 10 \\
${ }^{14} \mathrm{~N}^{2+}$ & 7 & 1.05 & 1.47 & 1.86 & 1.7 \\
${ }^{14} \mathrm{~N}^{2+}$ & 7 & 1.32 & 1.64 & 1.62 & 1.46 \\
${ }^{20} \mathrm{Ne}^{3+}$ & 6.67 & 1.03 & 1.4 & 2.2 & 2 \\
${ }^{22} \mathrm{Ne}^{2+}$ & 11 & 0.38 & 1.4 & 1.85 & 1.77 \\
${ }^{40} \mathrm{Ar}^{4+}$ & 10 & 0.65 & 1.64 & 1.5 & 1.4 \\
${ }^{40} \mathrm{Ar}^{5+}$ & 8 & 0.58 & 1.25 & 0.98 & 0.64 \\
${ }^{40} \mathrm{Ar}^{5+}$ & 8 & 0.98 & 1.63 & 0.61 & 0.52 \\
${ }^{40} \mathrm{Ar}^{6+}$ & 6.67 & 1.06 & 1.4 & 2 & 1.85 \\
${ }^{40} \mathrm{Ar}^{7+}$ & 5.71 & 1.14 & 1.25 & 1.92 & 2.83 \\
${ }^{84} \mathrm{Kr}^{12+}$ & 7 & 1 & 1.42 & 2.72 & \\
\hline
\end{tabular}

Extraction system consists of electrostatic deflector and focusing magnetic channel. Beam energy is varied from 0.35 to $0.8 \mathrm{MeV} /$ nucleon while ions are accelerated on the sixth harmonic of main cyclotron frequency, and from 0.75 to $1.77 \mathrm{MeV} /$ nucleon during acceleration on the fourth harmonic of RF.

Three-dimensional model of the cyclotron complex is presented in Fig. 1. The snapshot of the cyclotron facility is shown in Fig. 2. The beam transport system consists of specialized 


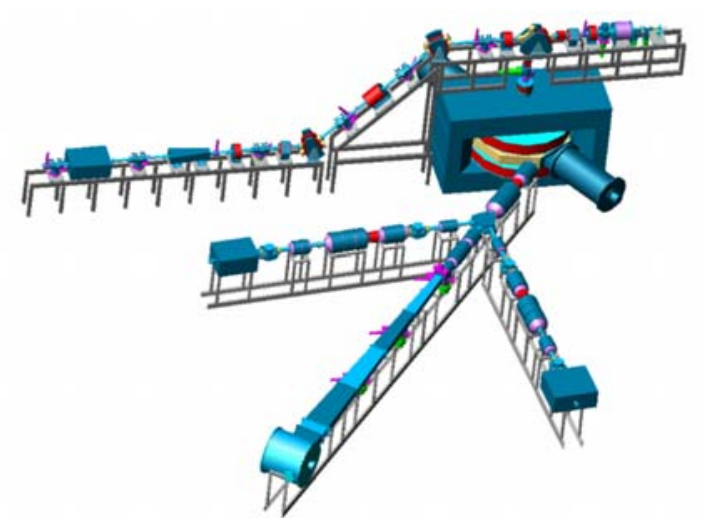

Fig. 1. Three-dimensional model of the DC60 facility

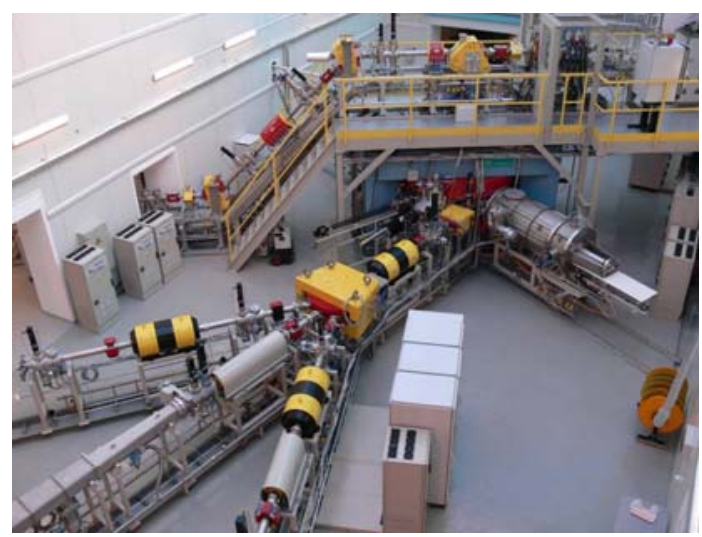

Fig. 2. Photo of the DC60 cyclotron facility

channel for irradiating polymer films and producing trace membranes, as well as of two channels for scientific research (Fig. 1) [9]. The cyclotron facility is supplied also with the low-energy beam channel in order to run experiments with heavy-ion beam of 10 to $25 Z$ energy ions supplied from the ECR source.

\section{INVESTIGATIONS OF ACCELERATED BEAMS}

After the DC60 cyclotron assembling and commissioning at Astana site it has been put into operation. The source operation was optimized; all cyclotron systems were adjusted and tuned to operational mode. The TM production channel was set up.

Set of experiments with accelerated beam was provided during first beam runs. Heavy ions in the wide range of mass-to-charge ratio $A / Z$ and of different energies were accelerated and delivered to the external target (see table). Projected parameters of accelerated and extracted ion beams have been successfully realized. The following experiments were performed: 
- Regimes of acceleration of nitrogen $\left({ }^{14} \mathrm{~N}^{2+}\right)$, argon $\left({ }^{40} \mathrm{Ar}^{4+},{ }^{40} \mathrm{Ar}^{5+},{ }^{40} \mathrm{Ar}^{7+}\right)$, krypton $\left({ }^{84} \mathrm{Kr}^{12+}\right)$ ions have been investigated at different levels of magnetic field, as well as for different radio frequencies and RF harmonics of acceleration.

- Operation and performance of RF buncher was investigated and set of measurements of bunching efficiency on injected beam intensity were carried out.

- Beam of krypton ions $\left({ }^{84} \mathrm{Kr}^{12+}\right)$ with intensity up to $2 \mu \mathrm{A}$ has been extracted into the beam channel, matched with proper shape and delivered to the technology device for polymer film irradiation. Required flux density and homogeneity of irradiation field was created. Experimental irradiation of polymer films was provided.

- Magnetic field correction by sets of trim coils was studied at different levels of main coil excitation. Heavy ions were accelerated and extracted at all levels of field.

Also beams of ${ }^{14} \mathrm{~N}^{2+},{ }^{20} \mathrm{Ne}^{2,3+},{ }^{40} \mathrm{Ar}^{4,5,6,7+},{ }^{84} \mathrm{Kr}^{12+}$ ions were accelerated at the DC60 cyclotron with objective to complete control of main cyclotron systems. Thereby the beam intensity during test runs was not set to maximum available values. We do hope to improve cyclotron performance and increase beam intensity up to $30 \mu \mathrm{A}$ for light ions $(\mathrm{N}, \mathrm{C}, \mathrm{O})$, up to $5 \mu \mathrm{A}$ for krypton ions and up to $3 \mu \mathrm{A}$ for Xe ions.

\section{CONCLUSION}

A facility based on DC60 cyclotron has been created for scientific and applied research, as well as for nanotechnologies application. During commissioning the first test beams of $\mathrm{N}$, $\mathrm{Ne}, \mathrm{Ar}, \mathrm{Kr}$ were accelerated in the energy range from 0.5 to $1.4 \mathrm{MeV} /$ nucleon. The beam parameters have been investigated, experimental polymer film irradiation was provided and track membranes were fabricated.

The presented results were obtained during first runs. One should expect that the beam intensity will be increased a few times and the range of accelerated ions will be much expanded.

The authors are grateful to FLNR (Dubna) and INP (Almaty) staff and all people who were participating in the Project and during launching of the facility.

\section{REFERENCES}

1. Gikal B. et al. Substantials for Funding of Interdisciplinary Scientific and Research Centre Based on Heavy Ion Cyclotron in Frame of Gumilev Euro-Asia National University. INP Report. Almaty, 2003. P. 67.

2. Apel' Yu. et al. // Nucl. Instr. Meth. B. 2003. V. 208. P. 11-20.

3. Gikal B. et al. Project of the DC60 Cyclotron with Smooth Ion Energy Variation for Research Center at Gumilev Euro-Asia National University in Astana (Kazakhstan) // Proc. of XVII Cycl. Conf. and Their Appl., Tokyo, 2004. P. 205-207.

4. Gikal B. et al. The DC60 Cyclotron Magnetic Field Measurements. JINR Preprint P9-2006-151. Dubna, 2006.

5. Efremov A. et al. Ion Source DECRIS-3 // Proc. of the 14th Intern. Workshop on ECRIS, CERN, Geneva, Switzerland, 1999. P.31. 
6. Efremov A. et al. // Rev. Sci. Instr. 1998. V.69, No.2. P. 679.

7. Gikal B. et al. The Axial Injection Channel for DC60 Cyclotron. JINR, P9-2006-39. Dubna, 2006.

8. Alexandrov A. et al. Space Charge Dominated Beams // Proc. of the Workshop on Physics for Heavy Ion Fusion ECR Sources, RIKEN, Japan, 1998. P. 49.

9. Gikal B. et al. The Beam Transport System for Heavy Ions Extracted from the DC60 Cyclotron. JINR, P9-2006-37. Dubna, 2006. 